\title{
Biochar can Increase Chinese Cabbage (Brassica oleracea L.) Yield, Decrease Nitrogen and Phosphorus Leaching Losses in Intensive Vegetable Soil
}

\author{
Haijun Sun ${ }^{1,2}$, Paramsothy Jeyakumar ${ }^{3}$, Hongdong $\mathrm{Xiao}^{2}$, Xuewen $\mathrm{Li}^{2}$, Jiayou Liu ${ }^{2}$, Min $\mathrm{Yu}^{2}$, Prabal Bir \\ Jung Rana ${ }^{1}$ and Weiming Shi ${ }^{2,4, *}$ \\ ${ }^{1}$ Co-Innovation Center for Sustainable Forestry in Southern China, College of Forestry, Nanjing Forestry University, Nanjing, \\ 210037, China \\ ${ }^{2}$ Department of Horticulture, College of Food Science and Technology, Foshan University, Foshan, 528000, China \\ ${ }^{3}$ Environmental Sciences, School of Agriculture and Environment, Massey University, Palmerston North, 4442, New Zealand \\ ${ }^{4}$ State Key Laboratory of Soil and Sustainable Agriculture, Institute of Soil Science, Chinese Academy of Sciences, Nanjing, 210008, \\ China \\ *Corresponding Author: Weiming Shi. Email: wmshi@issas.ac.cn
}

Received: 10 March 2021 Accepted: 29 June 2021

\begin{abstract}
There are few evidences on the effect of biochar on vegetable yield, nitrogen $(\mathrm{N})$ and phosphorus $(\mathrm{P})$ leaching losses under intensive vegetable production soil. The current field plot scale study evaluated responses of Chinese cabbage (Brassica oleracea L.) yield, $\mathrm{N}$ and $\mathrm{P}$ leaching losses using five $\mathrm{N}$ treatments of common $\mathrm{N}$ application rate according to local farmers' practice (N100\%), reducing $20 \%$ or $40 \% \mathrm{~N}$ fertilizer ( $\mathrm{N} 80 \%$ and $\mathrm{N} 60 \%$ ), and reducing $40 \% \mathrm{~N}$ fertilizer but incorporating 10 or $20 \mathrm{t} /$ ha biochar ( $60 \%+\mathrm{BC} 10$ and $\mathrm{N} 60 \%+\mathrm{BC} 20)$. Results showed that $\mathrm{N} 80 \%$ and $\mathrm{N} 60 \%$ decreased both the cabbage economic and leaf yields by $6.8 \%-36.3 \%$ and $27.4 \%-37.7 \%$, respectively. Incorporation of biochar with reduced $\mathrm{N}$ fertilizer rates improved the cabbage yield, in particular the N60\% + BC20 matched the yield that observed in N100\% treatment. Enhanced N and P uptake capacities of cabbage shoot probably contributed the higher vegetable production under both biochar amendment schemes. Biochar application mitigated the $\mathrm{NH}_{4}{ }^{+}-\mathrm{N}$ and total P leaching losses by $20 \%-30 \%$ and $29 \%-32 \%$, respectively, compared with their counterpart treatment $\mathrm{N} 60 \%$. Nevertheless, biochar exerted no influence on the $\mathrm{NO}_{3}{ }^{-} \mathrm{N}$ leaching. In addition, soil organic matter content was recorded with $7.4 \%-28.7 \%$ higher following $10-20 \mathrm{t} / \mathrm{ha}$ biochar application. In conclusion, biochar application can increase economic yield of cabbage via increasing $\mathrm{N}$ and $\mathrm{P}$ use efficiency, decrease $\mathrm{N}$ and $\mathrm{P}$ leaching losses, and improve soil quality in an intensive vegetable production system.
\end{abstract}

\section{KEYWORDS}

Biochar; leachate; non-point source pollution; vegetable yield; soil quality

\section{Introduction}

In China, the intensive use of inorganic nitrogen $(\mathrm{N})$ and phosphorus $(\mathrm{P})$ fertilizers for vegetable production systems is higher than that of the world average [1]. These intense fertilizer applications in croplands may lead to lowering the fertilizer use efficiency. For example, intensive vegetable production 
systems in some places reported with only a maximum of $40 \%$ of the $\mathrm{N}$ use efficiency (NUE) [2]. In addition to increase in cost of production, these inefficient use of organic $\mathrm{N}$ and $\mathrm{P}$ fertilizers lead to soil degradation and contamination of hydrosphere and atmosphere environments $[3,4]$. In particular, rapid accumulation of nitrate, phosphorus, and salinity in soils were found under intensive vegetable production systems in southern China, as results of high amount of fertilizer application [5-7]. Therefore, it is of great concern to mitigate leaching $\mathrm{N}$ and $\mathrm{P}$ losses from vegetable production systems to enhance soil and water quality in the agriculture environment.

Biochar, a solid material obtained from the thermochemical conversion of biomass in an oxygen-limited environment, has attained extensive attention due to its agronomical and environmental benefits in agroecosystems [8-11]. Regarding to the effects of biochar on $\mathrm{N}$ cycling in vegetable production system, many literatures reported its influences on $\mathrm{NH}_{3}$ volatilization and $\mathrm{N}_{2} \mathrm{O}$ emission from both stable crop and vegetable production systems [12-15]. Further, Dong et al. [16] observed the effect of biochar amendment on $\mathrm{N}$ release to percolation water in paddy soil. However, there have been relatively less evidences on the effect of biochar incorporation on the leaching $\mathrm{N}$ and $\mathrm{P}$ losses from vegetable soils. Well known, leaching is one of the main $\mathrm{N}$ and $\mathrm{P}$ losses pathway in vegetable production, which can be controlled by different mitigation practices such as improved fertilizer management, reduced water management, and catch crops [2,3,6]. Yang et al. [17] recently reported that the positive effects of different biochar amendments on leachate characterization of an agricultural soil.

At present, both the researchers and policy makers suggested that the $\mathrm{N}$ application rate is far higher than the actual demand of vegetable [18]. However, it is not practicable to reduce the $\mathrm{N}$ requirement in vegetable production systems as vegetable biomass is one of the major factors of the vegetable growers during the production processes. Therefore, it is important to pinpoint to mitigate the $\mathrm{N}$ and $\mathrm{P}$ leaching losses and increase the vegetable yield production at optimum rate of inorganic $\mathrm{N}$ and $\mathrm{P}$ application. Therefore, it is suggested to amend biochar with soil to improve $\mathrm{N}$ and $\mathrm{P}$ use efficiency in a vegetable production system.

The objectives of the current plot-scale field experiment were: 1) to assess the market yield of vegetable, $\mathrm{N}$ and $\mathrm{P}$ leaching losses at reduced chemical $\mathrm{N}$ application rate by $20 \%-40 \%$ of common $\mathrm{N}$ application rate according to local farmers' practice, 2) to measure the efficiency of biochar on enhancing vegetable yield and mitigating $\mathrm{N}$ and $\mathrm{P}$ leaching losses in soil system receiving reduced $\mathrm{N}$ fertilizer, and 3 ) to observe the changes in soil properties following $\mathrm{N}$ reduction and biochar application.

\section{Materials and Methods}

\subsection{Site Description and Soil Characteristics}

The field experiment was conducted in Datang Town, Foshan City, Guangdong Province $\left(23^{\circ} 34^{\prime} \mathrm{N}\right.$, $113^{\circ} 02^{\prime}$ E), located at Pearl River Delta region, Southern China. This location belongs to a subtropical maritime monsoon climate, with a mean annual precipitation and temperature of $1690 \mathrm{~mm}$ and $22.2^{\circ} \mathrm{C}$, respectively. The experiment was conducted from November 20, 2018 to March 30, 2019, to assess the responses of vegetable (Chinese cabbage, Brassica oleracea $\mathrm{L}$.) yield, leaching $\mathrm{N}$ and $\mathrm{P}$ losses, and soil properties to reduced application rates of organic $\mathrm{N}$ fertilizer and two rates of biochar. Before the establishment of the experiment, the site was evenly maintained under a typical open-field vegetable production managements for more than ten years. A bulk topsoil $(0-20 \mathrm{~cm})$ sample was collected from the experimental site and analyzed for soil characteristics. The topsoil was classified as Orthic Ferralsol, and showed following properties: $\mathrm{pH}$ (soil:water $=1: 5$ ) 6.56 , available $\mathrm{N} 139.6 \mathrm{mg} / \mathrm{kg}$, total N $0.5 \mathrm{~g} / \mathrm{kg}$, available P $154.7 \mathrm{mg} / \mathrm{kg}$, total P $0.48 \mathrm{~g} / \mathrm{kg}$, and organic matter $13.0 \mathrm{~g} / \mathrm{kg}$. Biochar used in this study was derived from canola (Brassica campestris L.) straw at $400^{\circ} \mathrm{C}$ and had a $\mathrm{pH}$ (biochar:water $=1: 5$ ) of 7.5, and contained $62.5 \%$ of $\mathrm{C}$ and $0.19 \%$ of $\mathrm{N}$. These selected properties of soil and biochar were measured according to that described in $\mathrm{Lu}[19]$. 


\subsection{Treatments and Management}

Five treatments were established in the field with different biochar and $\mathrm{N}$ application rates consisting: local farmers' practice $\mathrm{N}$ rate $\left(\mathrm{N} 100 \%, 130 \mathrm{~kg} \mathrm{ha}^{-1} \mathrm{~N}\right), 80 \%$ and $60 \%$ of practice $\mathrm{N}$ rate $(\mathrm{N} 80 \%$ and $\mathrm{N} 60 \%$ ), and $\mathrm{N} 60 \%$ with 10 and 20 t/ha biochar (N60\% + BC10 and N60\% + BC20). Each treatment was triplicated, and total fifteen plots (each plot was measured $15 \mathrm{~m} \times 2 \mathrm{~m}$ ) were arranged in a randomized complete block design (RCBD). The cabbage seeds were evenly sown at a rate of $200 \mathrm{~g}$ per plot and mixed with top 3-5 cm soil on November 20, 2018, and harvested on March 30, 2019. Due to the high nutrient demand of cabbage, $\mathrm{P}$ and potassium $(\mathrm{K})$ fertilizers were applied at the equal rates $(90 \mathrm{~kg}$ $\mathrm{P}_{2} \mathrm{O}_{5} / \mathrm{ha}$, and $120 \mathrm{~kg} \mathrm{~K} 2 \mathrm{O} / \mathrm{ha}$ ) to all treatments. The fertilizer $\mathrm{N}$ was split-applied on November 20, 2018 and December 21, 2018 with $50 \%$ and 50\% as basal and supplementary fertilizer, respectively. All $\mathrm{P}$ and $\mathrm{K}$ fertilizer were applied as one-time basal fertilizer. Nitrogen, $\mathrm{P}$ and $\mathrm{K}$ fertilizers were in the forms of urea $(\mathrm{N}, 46 \%)$, calcium superphosphate $\left(\mathrm{P}_{2} \mathrm{O}_{5}, 12 \%\right)$, and potassium chloride $\left(\mathrm{K}_{2} \mathrm{O}, 60 \%\right)$, respectively. Agronomic managements such as irrigation, weed and pest controls were conducted according to local farmers' traditional practice.

\subsection{Measurements}

\subsubsection{Yield, $N$ and $P$ Uptakes of Cabbage}

The cabbage yields were determined by measuring the quantity of fresh market value shoot biomass from each whole plot. Approximately $1 \mathrm{~kg}$ of fresh leafy vegetables samples from each plot were separately collected, washed with deionized water, and dried at $70^{\circ} \mathrm{C}$ in an oven to a constant weight. The dry leafy vegetable samples were digested with $\mathrm{H}_{2} \mathrm{SO}_{4}$ and $\mathrm{H}_{2} \mathrm{O}_{2}$ and used for the determination of total $\mathrm{N}$ and $\mathrm{P}$ concentrations by Kjeldahl and Molybdenum antimony colorimetric methods, respectively. The $\mathrm{N}$ and $\mathrm{P}$ concentrations were multiplied by the dry biomass weight to get the $\mathrm{N}$ and $\mathrm{P}$ uptake capacity of the cabbages.

\subsubsection{Soil Available $N$ and $P$, and Organic Matter}

Available $\mathrm{N}$ and $\mathrm{P}$ were extracted from five topsoil samples which randomly collected from each plot. Briefly, $100 \mathrm{~g}$ of soil was shaken with $200 \mathrm{~mL}$ of a $\mathrm{KCl}$ solution $(1 \mathrm{M})$ for $24 \mathrm{~h}$ and determined by continuous-flow colorimetric. Soil $\mathrm{C}$ content was measured by the external heating potassium dichromate oxidation-capacity method. Soil organic matter content was calculated by multiplying soil $\mathrm{C}$ content with a constant number of 1.724 .

\subsubsection{Leachate $N$ and $P$}

One year prior to the experiment, a lysimeter $(0.50 \mathrm{~m} \times 0.50 \mathrm{~m})$ was installed in each plot at a $0.50 \mathrm{~m}$ depth [6]. Each plot was separated with natural soil ditch in $0.5 \mathrm{~m}$ width to prevent cross movement of runoff water and nutrients. Leachate samples from lysimeters were collected on January 25, February 24, and March 20, 2019, respectively. After the volumes of leachate were recorded, $200 \mathrm{~mL}$ leachate was subsampled and frozen for the analysis of $\mathrm{pH}, \mathrm{NO}_{3}{ }^{-}-\mathrm{N}, \mathrm{NH}_{4}{ }^{+} \mathrm{N}$, and total $\mathrm{P}$ using the Continuous Flow Injection Analyzer (Skalar $\mathrm{San}^{++}$, the Netherlands).

\subsection{Statistical Analysis}

The difference among the five treatments was analyzed with a one-way analysis of variance (ANOVA). All tests of significance between pair treatments were conducted with Duncan's multiple-comparison tests $(P<0.05)$. All statistics and analyses were performed using Excel 2010 and the SPSS 16.0 for Windows. 


\section{Results and Discussion}

\subsection{Vegetable Production}

The impacts of fertilizer reduction and biochar application on cabbage economic yield and leaf biomass are presented in Fig. 1. The head yield and leaf biomass of cabbage among treatments were ranged from 25.0 to $42.2 \mathrm{t} / \mathrm{ha}$ and from 10.2 to $14.1 \mathrm{t} / \mathrm{ha}$, respectively. Reduced application of chemical $\mathrm{N}$ fertilizer by $20 \%-40 \%$ lowered both the head yield and leaf biomass by $6.8 \%-36.3 \%$ and $27.4 \%-37.7 \%$, respectively. This observation indicates that $\mathrm{N}$ is as the major nutrient for high production. The loss of the yield with reducing urea $\mathrm{N}$ fertilizer application by $20 \%-40 \%$, is in agreement with the previous studies [2,20,21]. This also suggests that local farmers had not over-applied $\mathrm{N}$ fertilizer for their vegetable production. However, the results showed that addition of biochar increased both the economic and leaf yield losses even when we reduced the chemical $\mathrm{N}$ inputs by $40 \%$. In particular, $\mathrm{N} 60 \%+\mathrm{BC} 10$ and $\mathrm{N} 60 \%+$ BC20 treatments increased the cabbage economic yield by $58.7 \%-68.8 \%$ compared with N60\%, which were equivalent to that observed under N100\% treatment (Fig. 1). Similarly, the leaf biomass of cabbage also increased with the addition of biochar treatments. Biochar amendment had been widely shown to increase plant productivity via improving soil physical properties [10], enhancing soil fertility [22], and providing nutrients contained in biochar itself [23]. Thus, the current study demonstrated that the vegetable production could be increased by biochar application at a10-20 t/ha rate, under reduced (60\%) $\mathrm{N}$ input treatments.

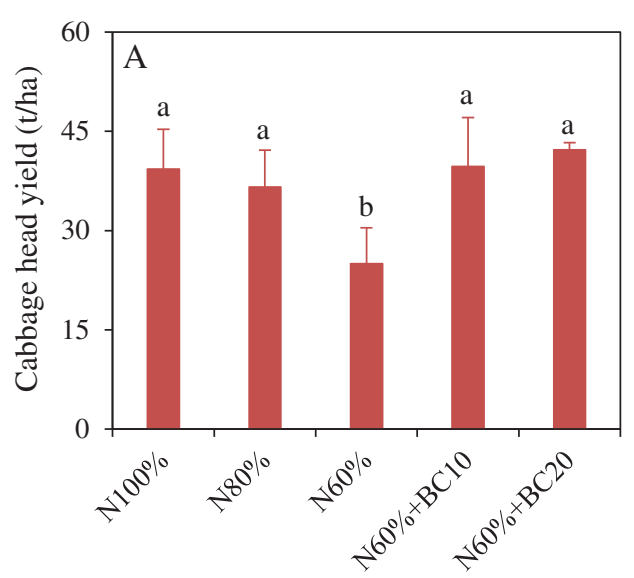

Treatments

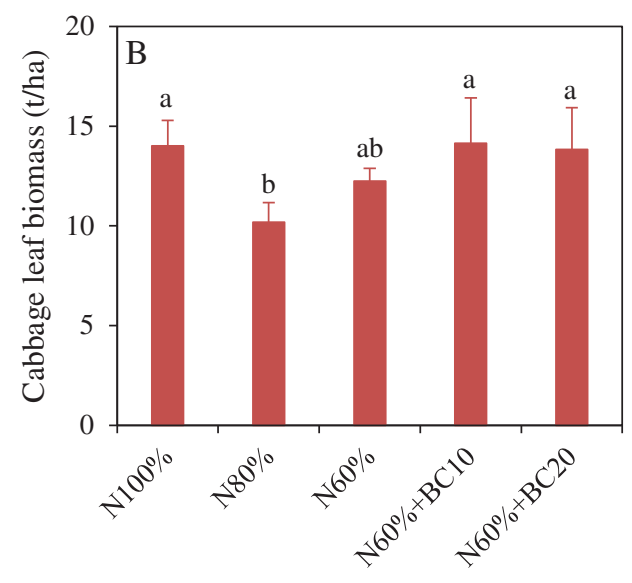

Treatments

Figure 1: Impacts of $\mathrm{N}$ reduction and biochar application on cabbage head yield (A) and leaf biomass (B). Error bars were the standard variation (SD) for the three replicates, and different lowercase letters indicate the significant difference between each treatment according to the Duncan multiple-comparison test at $P<0.05$

The reduction of $\mathrm{N}$ input (particularly under $\mathrm{N} 60 \%$ treatments) lowered the total $\mathrm{N}$ concentrations of both the cabbage head and leaf compared to the N100\% treatment (Tab. 1). Further, the addition of biochar also did not show any impact on the cabbage total $\mathrm{N}$ concentration in all treatments, except for $\mathrm{N} 60 \%+\mathrm{BC} 20$ treatment where it significantly $(P<0.05)$ increased the leaf total $\mathrm{N}$ concentration by $17.5 \%$ and $13.1 \%$, compared to $\mathrm{N} 60 \%$ and $\mathrm{N} 60 \%+\mathrm{BC} 10$, respectively. 
Table 1: Total $\mathrm{N}$ and $\mathrm{P}$ concentrations of tested vegetable shoot biomass

\begin{tabular}{llllll}
\hline \multirow{2}{*}{ Treatments } & \multicolumn{2}{c}{ Total N $(\mathrm{g} / \mathrm{kg})$} & & \multicolumn{2}{c}{ Total P $(\mathrm{g} / \mathrm{kg})$} \\
\cline { 2 - 3 } \cline { 5 - 6 } & Cabbage head & Cabbage leaf & & Cabbage head & Cabbage leaf \\
\hline $\mathrm{N} 100 \%$ & $21.2 \pm 2.1 \mathrm{a}$ & $12.3 \pm 0.1 \mathrm{a}$ & & $2.56 \pm 0.28 \mathrm{a}$ & $1.78 \pm 0.03 \mathrm{bc}$ \\
$\mathrm{N} 80 \%$ & $15.5 \pm 1.1 \mathrm{~b}$ & $11.6 \pm 0.5 \mathrm{ab}$ & & $2.35 \pm 0.09 \mathrm{a}$ & $1.74 \pm 0.07 \mathrm{~cd}$ \\
$\mathrm{~N} 60 \%$ & $14.4 \pm 0.4 \mathrm{~b}$ & $10.3 \pm 0.8 \mathrm{c}$ & & $2.23 \pm 0.04 \mathrm{a}$ & $1.66 \pm 0.01 \mathrm{~d}$ \\
$\mathrm{~N} 60 \%+\mathrm{BC} 10$ & $14.2 \pm 1.3 \mathrm{~b}$ & $10.7 \pm 0.8 \mathrm{bc}$ & & $2.36 \pm 0.26 \mathrm{a}$ & $1.85 \pm 0.09 \mathrm{~b}$ \\
$\mathrm{~N} 60 \%+\mathrm{BC} 20$ & $15.5 \pm 2.1 \mathrm{~b}$ & $12.1 \pm 0.3 \mathrm{a}$ & & $2.40 \pm 0.27 \mathrm{a}$ & $2.12 \pm 0.04 \mathrm{a}$ \\
\hline
\end{tabular}

Note: Data was mean $\pm \mathrm{SD}(n=3)$, and different lowercase letters in same column indicate the significant difference between each treatment according to the Duncan multiple-comparison test at $P<0.05$.

There was no significant $(P>0.05)$ difference observed in the total $\mathrm{P}$ concentration of cabbage head among all treatments. However, leaf total $\mathrm{P}$ concentration under N60\% treatment significantly $(P<0.05)$ lowered by $6.7 \%$ than that under $\mathrm{N} 100 \%$ treatment. In contrast, soil amendment with biochar at a rate of $10-20$ t/ha significantly $(P<0.05)$ increased the leaf total $\mathrm{P}$ concentration by $11.4 \%-27.7 \%$ compared to N60\%. Overall, the results suggest that addition of biochar to soil enhanced the $\mathrm{N}$ and $\mathrm{P}$ uptake capacities of vegetable shoot, which contributed the higher cabbage yield (Fig. 1 and Tab. 1).

\subsection{N and $P$ Leaching Losses}

Significant losses of $\mathrm{N}$ and $\mathrm{P}$ could occur after heavy chemical fertilization under open-field conditions which combined with high precipitation in the vegetable production systems in Eastern China [2,6]. In the current study, the $\mathrm{NH}_{4}{ }^{+}-\mathrm{N}, \mathrm{NO}_{3}{ }^{-}-\mathrm{N}$ and total $\mathrm{P}$ leaching losses from cabbage growth cycle under $\mathrm{N} 100 \%$ treatment were $0.20 \pm 0.02 \mathrm{~kg} / \mathrm{ha}, 20.9 \pm 1.3 \mathrm{~kg} / \mathrm{ha}$, and $0.38 \pm 0.02 \mathrm{~kg} / \mathrm{ha}$, respectively (Tab. 2). This is in agreement with previous studies, where the $\mathrm{NO}_{3}{ }^{-} \mathrm{-N}$ leaching loss was also the major concern under vegetable soil system [20,24]. Data in Tab. 2 suggested that reduced chemical $\mathrm{N}$ fertilizer application by $20 \%$ significantly $(P<0.05)$ decreased $25.0 \%$ of $\mathrm{NH}_{4}{ }^{+}-\mathrm{N}$ and $10.5 \%$ of total $\mathrm{P}$ leaching losses compared to $\mathrm{N} 100 \%$. Further, there was a significantly $(P<0.05)$ higher reduction of $\mathrm{NH}_{4}{ }^{+}-\mathrm{N}, \mathrm{NO}_{3}{ }^{-}-\mathrm{N}$ and total $\mathrm{P}$ losses by $50 \%, 22.5 \%$, and $26.3 \%$, respectively, when organic $\mathrm{N}$ input rate was decreased from $\mathrm{N} 100 \%$ to $\mathrm{N} 60 \%$. This implied that reduction of $\mathrm{N}$ input decreased its leaching losses [6,25]. However, data in Tab. 1 shows that the $\mathrm{N}$ and $\mathrm{P}$ uptake capacities have not been lowered under two reduced rates of $\mathrm{N}$ treatments. The change of $\mathrm{P}$ leaching loss is probably the result of the mismatch between $\mathrm{N}: \mathrm{P}$ stoichiometry and more studies should be conducted to confirm the related mechanisms in future.

Table 2: The $\mathrm{NH}_{4}{ }^{+}-\mathrm{N}, \mathrm{NO}_{3}{ }^{-}-\mathrm{N}$ and total $\mathrm{P}$ leaching losses under cabbage growth cycle

\begin{tabular}{llll}
\hline \multirow{2}{*}{ Treatments } & \multicolumn{3}{c}{$\mathrm{N}$ and $\mathrm{P}$ leaching losses $(\mathrm{kg} / \mathrm{ha})$} \\
\cline { 2 - 4 } & $\mathrm{NH}_{4}{ }^{+}-\mathrm{N}$ & $\mathrm{NO}_{3}{ }^{-}-\mathrm{N}$ & Total P \\
\hline $\mathrm{N} 100 \%$ & $0.20 \pm 0.02 \mathrm{a}$ & $20.9 \pm 1.3 \mathrm{a}$ & $0.38 \pm 0.02 \mathrm{a}$ \\
$\mathrm{N} 80 \%$ & $0.15 \pm 0.02 \mathrm{~b}$ & $21.1 \pm 1.7 \mathrm{a}$ & $0.34 \pm 0.01 \mathrm{~b}$ \\
$\mathrm{~N} 60 \%$ & $0.10 \pm 0.01 \mathrm{c}$ & $16.2 \pm 2.0 \mathrm{~b}$ & $0.28 \pm 0.01 \mathrm{c}$ \\
$\mathrm{N} 60 \%+\mathrm{BC} 10$ & $0.08 \pm 0.01 \mathrm{~d}$ & $14.6 \pm 0.8 \mathrm{~b}$ & $0.20 \pm 0.01 \mathrm{~d}$ \\
$\mathrm{~N} 60 \%+\mathrm{BC} 20$ & $0.07 \pm 0.02 \mathrm{~d}$ & $14.3 \pm 0.7 \mathrm{~b}$ & $0.19 \pm 0.01 \mathrm{~d}$ \\
\hline
\end{tabular}

Note: Data was mean $\pm \mathrm{SD}(n=3)$, and different lowercase letters in same column indicate the significant difference between each treatment according to the Duncan multiple-comparison test at $P<0.05$. 
The application of biochar either 10 or 20 t/ha rates did not show any influence on $\mathrm{NO}_{3}{ }^{-} \mathrm{N}$ leaching losses. However, the biochar applications wiht $10-20$ t/ha significantly $(P<0.05)$ mitigated the $\mathrm{NH}_{4}{ }^{+}-\mathrm{N}$ and total $\mathrm{P}$ leaching losses by $20 \%-30 \%$ and $29 \%-32 \%$, respectively, compared with their counterpart treatment $\mathrm{N} 60 \%$. Previous studies have found that biochar can absorb $\mathrm{NH}_{4}{ }^{+}-\mathrm{N}, \mathrm{NO}_{3}{ }^{-} \mathrm{N}$ and phosphate $[26,27]$. For example, Sika et al. [28] found that pine wood biochar effectively reduced both $\mathrm{NH}_{4}{ }^{+}-\mathrm{N}$ and $\mathrm{NO}_{3}{ }^{-} \mathrm{N}$ leaching losses by $12 \%-86 \%$ and $26 \%-96 \%$, respectively. Further, Ke et al. [29] found that biochar reduced P leaching by $11.4 \%-16.0 \%$ in Mollisol eggplant field in Northeast China.

In the current study, biochar application with 10-20 t/ha reduced only the $\mathrm{NH}_{4}{ }^{+}-\mathrm{N}$ and total $\mathrm{P}$ leaching losses (except $\mathrm{NO}_{3}{ }^{-}-\mathrm{N}$ leaching losses) under intensive vegetable system. The results showed that both $\mathrm{N}$ reduction and biochar application had no significant $(P>0.05)$ influence on leachate volumes over the Chinese cabbage growth cycle (Fig. 2A). This suggests that the mitigation effect of biochar on $\mathrm{NH}_{4}{ }^{+} \mathrm{N}$ and total $\mathrm{P}$ leaching could not be explained by the changes of leachate volumes.
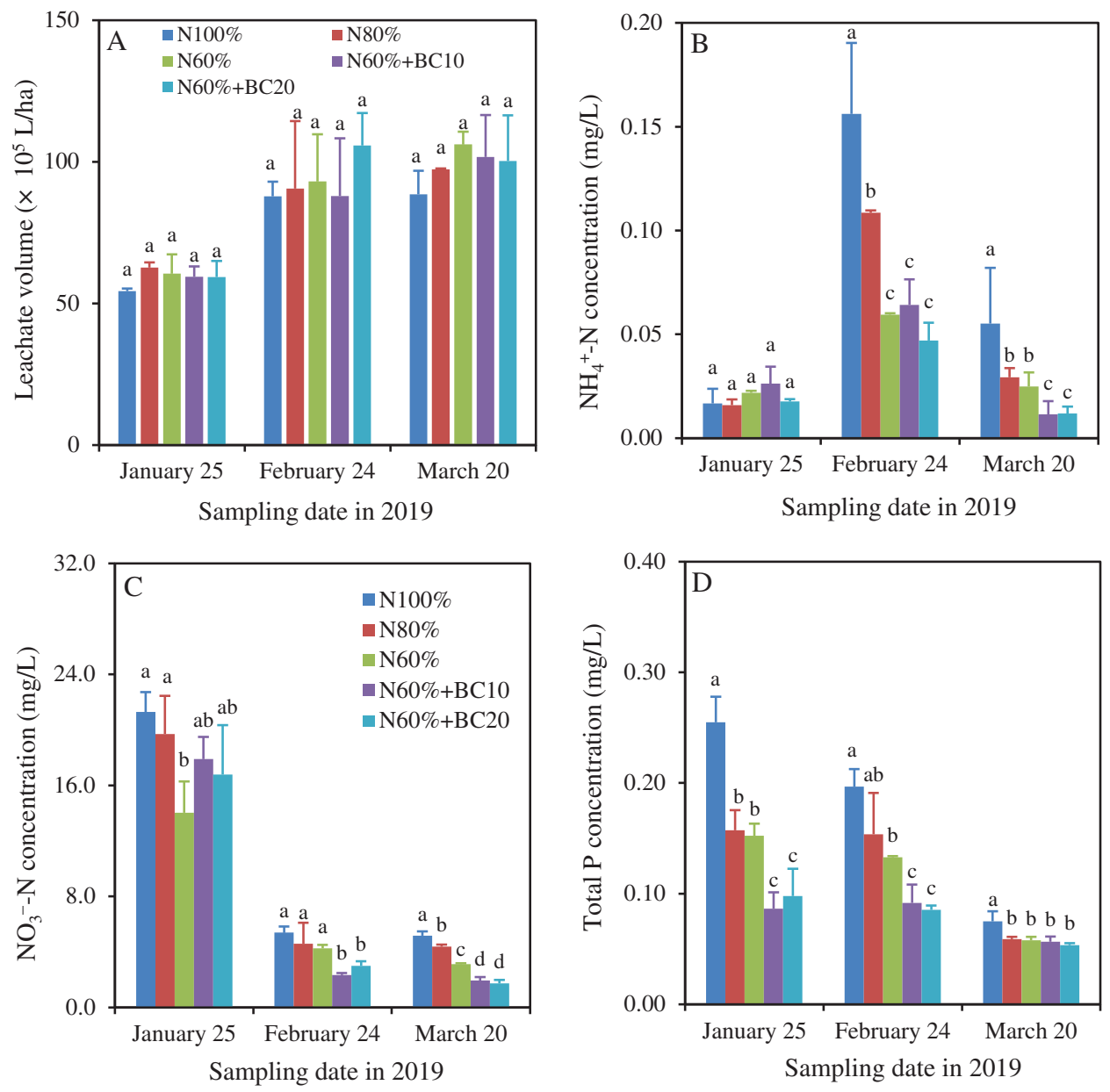

Figure 2: Impacts of fertilizer $\mathrm{N}$ reduction and biochar application on volume (A), $\mathrm{NH}_{4}{ }^{+}-\mathrm{N}(\mathrm{B}), \mathrm{NO}_{3}{ }^{-} \mathrm{N}$ (C), and total P (D) concentrations of leachates sampled on January 25, February 24, and March 20, 2019, respectively. Error bars were the standard variation (SD) for the three replicates, and different lowercase letters indicate the significant difference between each treatment according to the Duncan multiple-comparison test at $P<0.05$ 
The dynamics of leachate $\mathrm{NH}_{4}{ }^{+}-\mathrm{N}, \mathrm{NO}_{3}{ }^{-} \mathrm{N}$, and total $\mathrm{P}$ concentrations were summarized in Fig. 2. The reduction of $\mathrm{N}$ application by $20 \%-40 \%$ lowered the $\mathrm{NH}_{4}{ }^{+}-\mathrm{N}, \mathrm{NO}_{3}{ }^{-}-\mathrm{N}$ and total $\mathrm{P}$ concentrations in soil, which contributing to the lower $\mathrm{NH}_{4}{ }^{+}-\mathrm{N}, \mathrm{NO}_{3}{ }^{-} \mathrm{N}$ and total $\mathrm{P}$ leaching losses under $60 \%-80 \% \mathrm{~N}$ added treatments (Tab. 2). Further, data in Figs. $2 \mathrm{~B}$ and $2 \mathrm{D}$ showed that biochar amendment reduced the leachate $\mathrm{NH}_{4}{ }^{+}-\mathrm{N}$ and total $\mathrm{P}$ concentrations in most cases because of biochar's absorb functions as reported in previous literatures [26,27,30].

\subsection{Soil Properties}

Data in Tab. 3 showed that the lowering $\mathrm{N}$ inputs by $20 \%-40 \%$ increased the soil $\mathrm{pH}$ by $0.58-1.06$ units, which was observed under both with and without biochar added treatments. This result is in agreement with previous studies where they showed that the reduction of $\mathrm{N}$ application could relieve the soil acidification process in vegetable production system [4,5]. In general, biochar has the ability to increase the soil $\mathrm{pH}$ due to its alkaline properties $[31,32]$. However, the results showed that there was no significant $(P>$ 0.05 ) changes in soil $\mathrm{pH}$ of $60 \% \mathrm{~N}$ input treatments with or without biochar in the vegetable production system receiving $60 \%$ of common $\mathrm{N}$ input (Tab. 3). This may be attributing to the aging effect of biochar itself $[33,34]$ and the buffer capacity of soil $[35,36]$. Similarly, the soil total $\mathrm{N}$ and $\mathrm{P}$ concentrations, also did not show any difference under reduced $\mathrm{N}$ treatments whether received biochar or not in a short-term. However, both fertilizer $\mathrm{N}$ reduction and biochar application affected the soil organic matter content. In particular, $60 \% \mathrm{~N}$ treatment decreased the soil organic matter by $9.6 \%$. In contrast, $60 \% \mathrm{~N}+$ BC20 significantly $(P<0.05)$ increased the soil organic matter by $16.3 \%$. Biochar derived organic matter (BDOM) plays an important role in determining biochar's impacts in soil characteristics [37,38], such as increasing the soil organic matter content in the current study (Tab. 3). Of course, the long-term effect of reducing $\mathrm{N}$ fertilizer and applying biochar on properties of intensive vegetable soil should be investigated in future.

Table 3: Responses of selected soil properties to fertilizer $N$ reduction and biochar application

\begin{tabular}{lllll}
\hline Treatments & $\mathrm{pH}$ & $\begin{array}{l}\text { Total N } \\
(\mathrm{mg} / \mathrm{kg})\end{array}$ & $\begin{array}{l}\text { Total P } \\
(\mathrm{g} / \mathrm{kg})\end{array}$ & $\begin{array}{l}\text { Organic matter } \\
(\%)\end{array}$ \\
\hline $100 \%$ & $6.12 \pm 0.10 \mathrm{~b}$ & $1.22 \pm 0.12 \mathrm{a}$ & $0.59 \pm 0.03 \mathrm{a}$ & $1.35 \pm 0.03 \mathrm{bc}$ \\
$\mathrm{N} 80 \%$ & $6.70 \pm 0.48 \mathrm{a}$ & $1.08 \pm 0.18 \mathrm{a}$ & $0.60 \pm 0.01 \mathrm{a}$ & $1.44 \pm 0.02 \mathrm{~b}$ \\
$\mathrm{~N} 60 \%$ & $7.18 \pm 0.02 \mathrm{a}$ & $1.13 \pm 0.12 \mathrm{a}$ & $0.60 \pm 0.02 \mathrm{a}$ & $1.22 \pm 0.02 \mathrm{~d}$ \\
$\mathrm{~N} 60 \%+\mathrm{BC} 10$ & $6.72 \pm 0.04 \mathrm{a}$ & $1.14 \pm 0.12 \mathrm{a}$ & $0.58 \pm 0.03 \mathrm{a}$ & $1.31 \pm 0.07 \mathrm{~cd}$ \\
$\mathrm{~N} 60 \%+\mathrm{BC} 20$ & $6.98 \pm 0.35 \mathrm{a}$ & $1.09 \pm 0.17 \mathrm{a}$ & $0.67 \pm 0.14 \mathrm{a}$ & $1.57 \pm 0.09 \mathrm{a}$ \\
\hline
\end{tabular}

Note: Data was mean \pm SD $(n=3)$, and different lowercase letters in same column indicate the significant difference between each treatment according to the Duncan multiple-comparison test at $P<0.05$.

\section{Conclusions}

Current field study demonstrated that there is a loss in vegetable yield when the $\mathrm{N}$ fertilizers were reduced by $20 \%-40 \%$ from farmers' common fertilizer management. However, the application of biochar with 10-20 tha could increase the cabbage production even under $60 \%$ of common practiced $\mathrm{N}$ treatments and matched with the yield performed with full rate of $\mathrm{N}$ applied treatments. Further, biochar addition at a rate of 10-20 t/ha effectively mitigated the $\mathrm{NH}_{4}{ }^{+}-\mathrm{N}$ and total $\mathrm{P}$ leaching losses by $20 \%$ $30 \%$ and $29 \%-32 \%$, respectively, which was mainly due to the lower $\mathrm{NH}_{4}{ }^{+}-\mathrm{N}$ and total $\mathrm{P}$ concentrations of leachate. No response was observed in soil $\mathrm{pH}$, total $\mathrm{N}$ and $\mathrm{P}$ contents following the biochar application to vegetable soil in short-term. However, biochar amendments increased the soil organic matter content, particularly when being applied at a higher rate (20 t/ha in current work). 
Acknowledgement: We thank Mr. Shuying Li and Ms. Xin Fan for taking leachate and soil samples and analyzing some selected properties of experiment samples.

Funding Statement: This work was financially supported by the National Key Research and Development Program of China (2018YFD0800204,), the National Natural Science Foundation of China (31972518), and Qing Lan Project of Jiangsu Province.

Conflicts of Interest: The authors declare that they have no conflicts of interest to report regarding the present study.

\section{References}

1. Wu, Y. H., Wang, E. R., Miao, C. H. (2019). Fertilizer use in China: The role of agricultural support policies. Sustainability, 11(16), 4391. DOI 10.3390/su11164391.

2. Min, J., Sun, H. J., Kronzucker, H. J., Wang, Y., Shi, W. M. (2021). Comprehensive assessment of the effects of nitrification inhibitor application on reactive nitrogen loss in intensive vegetable production systems. Agriculture, Ecosystems and Environment, 307, 107227. DOI 10.1016/j.agee.2020.107227.

3. Bai, X. L., Zhang, Z. B., Cui, J. J., Liu, Z. J., Chen, Z. J. et al. (2020). Strategies to mitigate nitrate leaching in vegetable production in China: A meta-analysis. Environmental Science and Pollution Research, 27(15), 18328-18391. DOI 10.1007/s11356-020-08322-1.

4. Shi, W. M., Yao, J., Yan, F. (2009). Vegetable cultivation under greenhouse conditions leads to rapid accumulation of nutrients, acidification and salinity of soils and groundwater contamination in South-Eastern China. Nutrient Cycling in Agroecosystems, 83(1), 73-84. DOI 10.1007/s10705-008-9201-3.

5. Min, J., Shi, W. M., Xing, G. X., Zhang, H. L., Zhu, Z. L. (2011). Effects of a catch crop and reduced nitrogen fertilization on nitrogen leaching in greenhouse vegetable production systems. Nutrient Cycling in Agroecosystems, 91(1), 31-39. DOI 10.1007/s10705-011-9441-5.

6. Liu, L., Zhang, X. Y., Xu, W., Liu, X. J., Wei, J. et al. (2020). Challenges for global sustainable nitrogen management in agricultural systems. Journal of Agricultural and Food Chemistry, 68(11), 3354-3361. DOI 10.1021/acs.jafc.0c00273.

7. Xiao, H. D., Fan, X., Sun, H. J., Yu, M., Shi, W. M. et al. (2020). The benefit of leafy vegetable as catch crop to mitigate $\mathrm{N}$ and $\mathrm{P}$ leaching losses in intensive plastic-shed production system. Journal of Soils and Sediments, 21(6), 2253-2261. DOI 10.1007/s11368-021-02930-1.

8. Chu, L., Darshika Hennayake, H. M. K., Sun, H. J. (2019). Biochar effectively reduces ammonia volatilization from nitrogen-applied soils in tea and bamboo plantations. Phyton-International Journal of Experimental Botany, 88(3), 261-266. DOI 10.32604/phyton.2019.07791.

9. Ding, S. H., Fang, S. Z., Tian, Y., Song, Z. Q., Zhang, Y. H. (2020). Analysis and evaluation on physicochemical properties of poplar biochar at different pyrolysis temperature. Journal of Nanjing Forestry University (Natural Sciences Edition), 14(6), 193-200. DOI 10.3969/j.issn.1000-2006.201910005.

10. Long, Q. N., Wang, R. S., Xu, H. M., Cao, G. H., Shen, C. Q. et al. (2020). Effects of biogas slurry and biochar on oribatida density in poplar plantation. Journal of Nanjing Forestry University (Natural Science Edition), 44(3), 211-215. DOI 10.3969/j.issn.1000-2006.201904023.

11. Lu, W. W., Zhang, Y. R., Yao, Y. X., Wu, Y. Y., Chen, H. Y. H. et al. (2020). Biochar-induced priming effects in young and old poplar plantation soils. Phyton-International Journal of Experimental Botany, 89(1), 13-26. DOI 10.32604/phyton.2020.09125.

12. Liu, J. Y., Shen, J. L., Li, Y., Su, Y. R., Ge, T. D. et al. (2014). Effects of biochar amendment on the net greenhouse gas emission and greenhouse gas intensity in a Chinese double rice cropping system. European Journal of Soil Biology, 65, 30-39. DOI 10.1016/j.ejsobi.2014.09.001.

13. Duan, P. P., Zhou, J., Feng, L., Jansen-Willems, A. B., Xiong, Z. Q. (2019). Pathways and controls of $\mathrm{N}_{2} \mathrm{O}$ production in greenhouse vegetable production soils. Biology and Fertility of Soils, 55, 285-297. DOI 10.1007/ s00374-019-01348-9. 
14. Fungo, B., Lehmann, J., Kalbitz, K., Thionǵo, M., Tenywa, M. et al. (2019). Ammonia and nitrous oxide emissions from a field Ultisol amended with tithonia green manure, urea, and biochar. Biology and Fertility of Soils, 55, 135148. DOI 10.1007/s00374-019-01348-9.

15. Sun, H. J., Feng, Y. F., Xue, L. H., Mandal, S., Wang, H. L. et al. (2020). Responses of ammonia volatilization from rice paddy soil to application of wood vinegar alone or combined with biochar. Chemosphere, 242, 125247. DOI 10.1016/j.chemosphere.2019.125247.

16. Dong, D., Wang, C., van Zwieten, L., Wang, H. L., Jiang, P. K. et al. (2019). An effective biochar-based slowrelease fertilizer for reducing nitrogen loss in paddy soils. Journal of Soils and Sediments, 20, 3027-3040. DOI 10.1007/s11368-019-02401-8.

17. Yang, X. Y., Chang, K., Kim, Y. J., Zhang, J., Yoo, G. (2019). Effects of different biochar amendments on carbon loss and leachate characterization from an agricultural soil. Chemosphere, 226, 625-635. DOI 10.1016/j. chemosphere.2019.03.085.

18. Wu, Y. Y., Xi, X. C., Tang, X., Luo, D. M., Gu, B. J. et al. (2018). Policy distortions, farm size, and the overuse of agricultural chemicals in China. Proceedings of the National Academy of Sciences of the United States of America, 115(27), 201806645. DOI 10.1073/pnas.1806645115.

19. Lu, R. K. (1999). Agricultural analysis methods for soils. China: China Agricultural Science and Technology Press.

20. Zhao, C. S., Hu, C. X., Huang, W., Sun, X. C., Tan, Q. L. et al. (2010). A lysimeter study of nitrate leaching and optimum nitrogen application rates for intensively irrigated vegetable production systems in Central China. Journal of Soils and Sediments, 10, 9-17. DOI 10.1007/s11368-009-0063-3.

21. Chen, H., Zhou, J., Li, B., Xiong, Z. Q. (2019). Yield-scale $\mathrm{N}_{2} \mathrm{O}$ emissions as affected by nitrification inhibitor and overdose fertilization under an intensively managed vegetable field: A three-year field study. Atmospheric Environment, 206, 247-257. DOI 10.1016/j.atmosenv.2019.02.036.

22. Spokas, K. A., Novak, J. M., Venterea, R. T. (2012). Biochar's role as an alternative N-fertilizer: Ammonia capture. Plant and Soil, 350(1-2), 35-42. DOI 10.1007/s11104-011-0930-8.

23. Xiao, X., Chen, B. L., Zhu, L. Z. (2014). Transformation, morphology, and dissolution of silicon and carbon in rice straw-derived biochars under different pyrolytic temperatures. Environmental Science and Technology, 48(6), 3411-3419. DOI 10.1021/es405676h.

24. Zhang, B. G., Li, Q., Cao, J., Zhang, C. Y., Song, Z. et al. (2017). Reducing nitrogen leaching in a subtropical vegetable system. Agriculture, Ecosystems \& Environment, 241(7523), 133-141. DOI 10.1016/j. agee.2017.03.006.

25. Constantin, J., Mary, B., Laurent, F., Aubrion, G., Fontaine, A. et al. (2010). Effects of catch crops, no till and reduced nitrogen fertilization on nitrogen leaching and balance in three long-term experiments. Agriculture, Ecosystem and Environment, 135(4), 268-278. DOI 10.1016/j.agee.2009.10.005.

26. Soinne, H., Hovi, J., Tammeorg, P., Turtola, E. (2014). Effect of biochar on phosphorus sorption and clay soil aggregate stability. Geoderma, 219-220(6), 162-167. DOI 10.1016/j.geoderma.2013.12.022.

27. Takaya, C. A., Fletcher, L. A., Anyikude, K. U., Ross, A. B. (2016). Phosphate and ammonium sorption capacity of biochar and hydrochar from different wastes. Chemosphere, 145, 518-527. DOI 10.1016/j. chemosphere.2015.11.052.

28. Sika, M. P., Hardie, A. G. (2014). Effect of pine wood biochar on ammonium nitrate leaching and availability in as South African sandy soil. European Journal of Soil Science, 65, 113-119. DOI 10.1111/ejss.12082.

29. Ke, Z., Sui, Y. Y., Xu, X., Zhang, J. Y., Chen, Y. M. et al. (2018). The effects of biochar addition on phosphorus transfer and water utilization efficiency in a vegetable field in Northeast China. Agricultural Water Management, 210, 324-329. DOI 10.1016/j.agwat.2018.08.007.

30. Sun, H. J., Lu, H. Y., Chu, L., Shao, H. B., Shi, W. M. (2017). Biochar applied with appropriate rates can reduce N leaching, keep $\mathrm{N}$ retention and not increase $\mathrm{NH}_{3}$ volatilization in a coastal saline soil. Science of the Total Environment, 575, 820-825. DOI 10.1016/j.scitotenv.2016.09.137.

31. Kannan, P., Paramasivan, M., Marimuthu, S., Swaminathan, C., Jayakumar, B. (2021). Applying both biochar and phosphobacteria enhances Vigna mungo L. growth and yield in acid soils by increasing soil pH, moisture content, 
microbial growth and P availability. Agriculture, Ecosystem \& Environment, 308, 107258. DOI 10.1016/j. agee.2020.107258.

32. Verhoeven, E., Six, J. (2014). Biochar does not mitigate field-scale $\mathrm{N}_{2} \mathrm{O}$ emissions in a Northern California vineyard: An assessment across two years. Agriculture, Ecosystem \& Environment, 191, 27-38. DOI 10.1016/j. agee.2014.03.008.

33. Rechberger, M., Kloss, S., Rennhofer, H., Tintner, J., Watzinger, A. et al. (2017). Changes in biochar physical and chemical properties: Accelerated biochar aging in an acidic soil. Carbon, 115, 209-219. DOI 10.1016/j. carbon.2016.12.096.

34. Li, H. X., Lu, X. Q., Xu, Y., Liu, H. T. (2019). How close is artificial biochar aging to natural biochar aging in fields? A meta-analysis. Geoderma, 352, 96-103. DOI 10.1016/j.geoderma.2019.06.006.

35. Furian, S., Mohamedou, A. O., Hammecker, C., Maeght, J. L., Barbiero, L. (2011). Soil cover and landscape evolution in the Senegal floodplain: A review and synthesis of processes and interactions during the late Holocene. European Journal of Soil Science, 62(6), 902-912. DOI 10.1111/j.1365-2389.2011.01398.x.

36. Sakala, G. M., Rowell, D. L., Pilbeam, C. J. (2004). Acid-base reactions between an acidic soil and plant residues. Geoderma, 123(3-4), 219-232. DOI 10.1016/j.geoderma.2004.02.002.

37. Jin, J., Sun, K., Yang, Y., Wang, Z. Y., Han, L. F. et al. (2018). Comparison between soil-and biochar-derived humic acids: Composition, conformation, and phenanthrene sorption. Environmental Science and Technology, 52(4), 1880-1888. DOI 10.1021/acs.est.7b04999.

38. Smebye, A., Alling, V., Vogt, R. D., Gadmar, T. C., Mulder, J. et al. (2016). Biochar amendment to soil changes dissolved organic matter content and composition. Chemosphere, 142, 100-105. DOI 10.1016/j. chemosphere.2015.04.087. 